\title{
Erratum to: Complement: Coming Full Circle
}

\author{
Gaëlle Le Friec $\cdot$ Claudia Kemper
}

Published online: 10 April 2010

(C) L. Hirszfeld Institute of Immunology and Experimental Therapy, Wroclaw, Poland 2010

Erratum to: Arch Immunol Ther Exp (2009) 57:393-407

DOI 10.1007/s00005-009-0047-4

The elements of the first author's name were wrongly coded in the metadata of this article, with the result that the name was listed incorrectly in all indexing services. Her given name is Gaëlle; her surname, Le Friec.

The online version of the original article can be found under doi:10.1007/s00005-009-0047-4.

G. Le Friec · C. Kemper $(\bowtie)$

King's College London, MRC Centre for Transplantation,

Guy's Hospital 5th Floor Tower Wing, Great Maze Pond, London SE1 9RT, UK

e-mail: Claudia.kemper@kcl.ac.uk 